\title{
Vol. 2
}

No. 2

\section{INTERNATIONAL}

\section{JOURNAL OF}
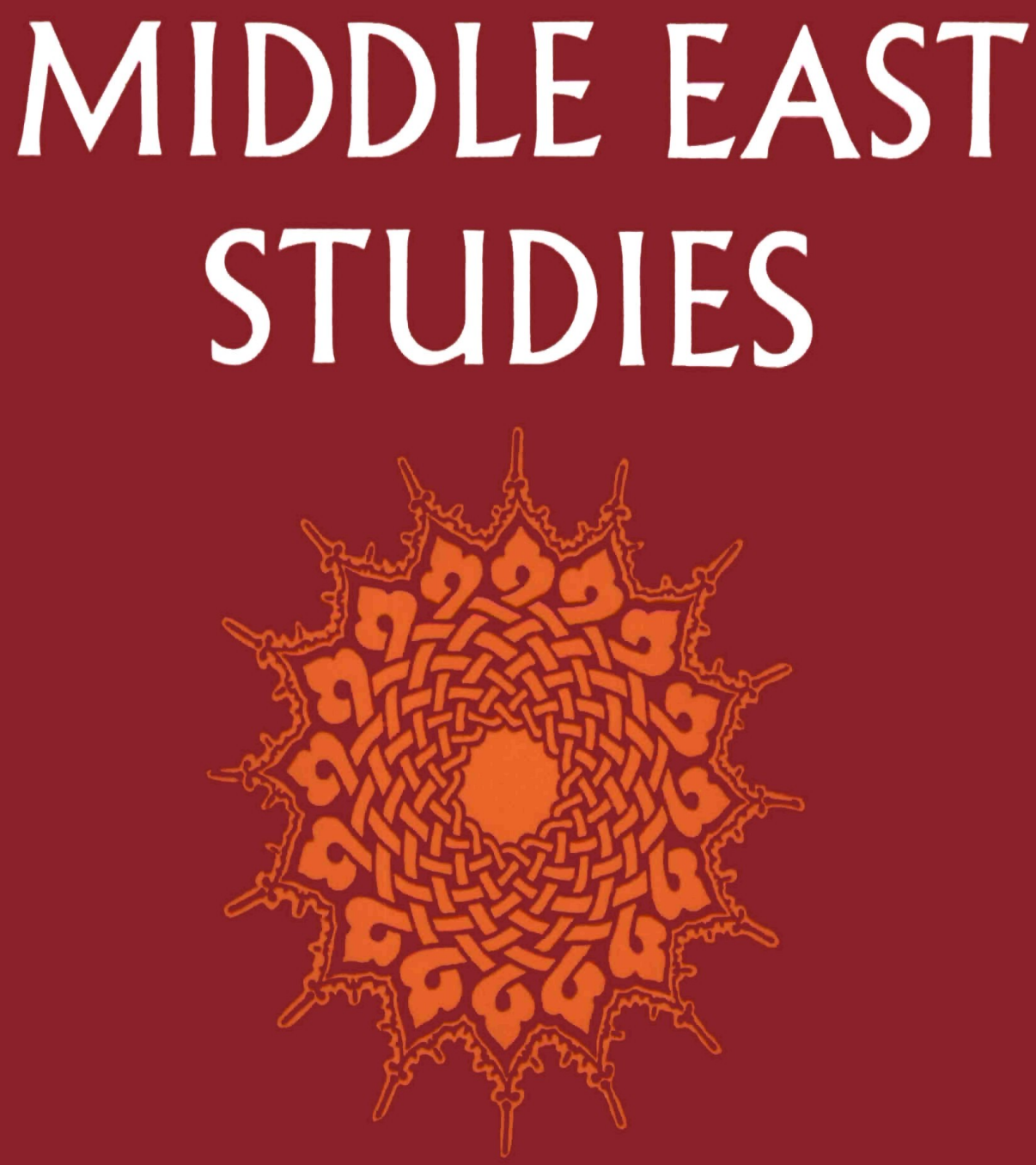


\title{
INTERNATIONAL JOURNAL OF MIDDLE EAST STUDIES
}

\author{
E D ITOR \\ STANFORD J. SHaW \\ Professor of Turkish and Near Eastern History \\ University of California, Los Angeles
}

EDITORIAL BOARD
William M. Brinner, University of Califormia, Berkeley, California
Oleg Gra Ba R, Harvard University, Cambridge, Massachusetts
Charles Issawi, Columbia University, New York, N.Y.
Malcolm Kerr, University of California, Los Angeles, California
Kamal Salibi, American University of Beirut, Lebanon
R. B. Serjeant, Cambridge University, Cambridge, England
roger Le'Tourneav, Université d'Aix-Marseille, France
Nur Yalman, University of Chicago, Chicago, Illinois

The International fournal of Middle East Studies publishes articles and reviews concerning the area encompassing Iran, Turkey, Afghanistan, Israel, Pakistan, and the countries of the Arab World from the seventh century to modern times. Spain, Southeastern Europe, and the Soviet Union also are included for the periods in which their territories were parts of Middle Eastern empires or were under the influence of Middle Eastern civilization. Particular attention will be paid to works dealing with history, political science, economics, anthropology, sociology, philology and literature, folklore, comparative religion and theology, law and philosophy. Authors also are encouraged to submit reports on archives and other source materials uncovered during the course of their research which would be of particular interest to other scholars in the field.

The International Journal of Middle East Studies is published quarterly. Single parts cost $\mathcal{L}_{1} \mathrm{1} .30$ net $(\$ 4.00$ in the U.S.A.) plus postage. Four parts form a volume. The subscription price of a volume (which includes postage) is $£_{4}$ net ( $\$ 12.50$ in the U.S.A.). Orders may be sent to a bookseller or to Cambridge University Press, P.O. Box 92, London, N.W.I, or to Cambridge University Press, 32 East $57^{\text {th }}$ Street, New York, N.Y. 10022.

Second class postage paid at New York, N.Y.

\section{Notes for Contributors}

Contributions and editorial correspondence should be sent to the Editor, Professor Stanford J. Shaw, Near Eastern Center, Ralph Bunche Hall, University of California, Los Angeles, California, 90024 , U.S.A. Submission of an article implies that it has not previously been published, or is not being considered for publication elsewhere. Articles should normally not exceed 30 typewritten pages, quarto, double-spaced, but longer contributions may be submitted by agreement with the Editor. Articles in English should conform with the Journal's transliteration system. Articles will be accepted and published in French and German, with the authors expected to follow the transliteration systems normally used in those languages. Both text and footnotes should be clearly typed with double spacing and wide left-hand margins.

General notes intended for the Editor and the printer should be attached on a separate sheet. Contributors should keep at least one copy of the typescript for use in correcting proofs.

First proofs may be read and corrected by contributors provided they give an address where they can be reached without delay and can guarantee to return the corrected proofs to the Editor, by airmail where appropriate, within ten days of receiving them. The master proof will be sent direct to the Editor by the printer, with the contributors receiving duplicates to be returned to the Editor.

Contributors of articles and review articles receive 50 offprints. Extra copies may be purchased https://doi.org/10.1917/S00207438000009 9 Published online by Cambridge University Press
according to an agreed scale of charges. 